\section{GEORGE GRIFFITH.}

$\mathrm{T}$ $\mathrm{HE}$ news of the sudden death of Mr. George Griffith, Assistant General Secretary to the British Association, came as a shock to all who were acquainted with his vigorous personality. On the afternoon of May 7 he left the office of the British Association apparently in his usual health, and took his place in the train from Baker Street Station for Harrow. Scarcely had the train started when he was seized with an attack which ended fatally in a few minutes.

Griffith's career was divided into three periods-his Oxford life, his long tenure of an assistant mastership at Harrow School, and the last twelve years of his life occupied with his duties as assistant general secretary of the British Association.

His career at Jesus College, Oxford, was a brilliant one. After taking honours both in classical and mathematical moderations, his name appears, alone, in the first class in the final school of natural science in 1856 . For the next eleven years he resided at Oxford, where he married a daughter of Mr. A. H. D. Acland Troyte. Toward the latter end of this period he was appointed deputy for the professor of natural philosophy, from which position he was summoned in 1867 by Dr. Butler to inaugurate the teaching of natural science at Harrow.

The task before the new-comer was by no means easy. The teaching of science, which had been forced on the attention of reluctant governing bodies by the recommendations of the Endowed Schools Commission, was regarded with scant favour by the majority of schoolmasters, while among the boys it was frankly disliked. At Harrow there was at that time neither laboratory nor special class-room; Griffith was allowed the use of a room when it was not being used by another master, but all apparatus had to be cleared away after each lecture before the entrance of the legitimate tenant. This state of things continued until about 1874, when properly equipped laboratories were erected. For twenty-six years (1867-93) Griffith taught at Harrow, in his earlier years taking physics, chemistry, geology and biology, according to the demand; latterly he confined himself almost exclusively to physics. In $187 \mathrm{I}$ he entered into possession of a "Small House" (a boarding-house for nine boys), which he held until, in 1887 , he succeeded $\mathrm{Mr}$. Holmes as the master of "Druries," a larger and more responsible charge. In 1893 he retired from his mastership, having already been appointed (in I 890) assistant general secretary to the British Association for the second time.

His active connection with the British Association began at a much earlier date. We find him acting as local secretary at the Oxford meeting of 1860 , memorable for the Huxley-Wilberforce battle over Darwin's works, while in 1862 he entered on his first term of office as assistant general secretary. Having resigned in 1878 , he was prevailed upon to take charge of the work for the year I88I, during a temporary vacancy. In 1890 he was re-appointed, and carried on the work of his office with full vigour until an hour before his death.

During his latter years he threw himself with characteristic energy into the Royal Society's scheme for an international catalogue of scientific literature, a task for which he was singularly well fitted by wide learning, both scientific and linguistic, his unfailing memory and his fastidious accuracy of thought and expression.

He was laid to rest, on May $\mathrm{I}_{3}$, in the old churchyard of Harrow-on-the-Hill, above the little town that had been his home for thirty-five years, and the old school into which he had been the first to introduce the systematic teaching of science.

B. P. L.

\section{NOTES}

M. T. Moureaux, who has for twenty years been connected with the magnetic work of the Parc Saint-Maur Observatory, has been appointed to succeed the late M. Renou as director of the Observatory.

Prof. T. C. Chamberlin, of Chicago, Dr. T. Thoroddsen, of Reykjavik (Iceland), and Prof. S. W. Williston, of the University of Kansas, have been elected foreign correspondents of the Geological Society.

THE Prince of Wales has consented to become an honorary member of the Linnean Society. The following gentlemen have been elected foreign members of the Society:--MM. A. Giard, H. J. Hansen, C. S. Sargent, F. E. Schulze and J. Wiesner.

ON Tuesday next, May 20, Prof. Karl Pearson will deliver the first of three lectures at the Royal Institution on "The Laws of Heredity, with Special Reference to Man." The Friday evening discourse on May 30 will be delivered by Mr. G. Marconi, on "Electric Space Telegraphy," and that on June 6 by Sir Benjamin Baker, on "The Nile Reservoirs and Dams.'

THE new botanical laboratories, presented to University College, Liverpool, by Mr. W. P. Hartley, were opened by Sir William Thiselton-Dyer, K.C.M.G., F.R.S., on Saturday last. The new Institute is an imposing building and the accommodation it affords will facilitate the adrancement of the science of botany in Liverpool. The teaching of large classes of University students of botany is now not only possible, but easy; and in view of the probable early realisation of a University for Liverpool, this is a matter of some importance. Not only does Mr. Hartley's gift provide ample room for all probable increase in number of students, but the laboratories are equipped with the necessary appliances, both for elementary and advanced work. A special laboratory is set apart for investigations in plant physiology and another for anatomical research. The labora. tories will thus not only become centres of teaching, but of work carried on with the view of contributing knowledge which will assist the progress of botanical science. We hope to give a description of the new Institute in a later issue.

LIVERPOOL has often given evidence of its appreciation of the men of light and leading whose activities bring honour to the city. The return of Prof. Herdman from Ceylon, where he has recently spent several months in the investigation of the Pearl Oyster Fisheries, on behalf of the Government, provided Liverpool biologists and others with an opportunity of expressing their esteem for his work. A large company, including the Lord Mayor and Lady Mayoress, assembled at a complimentary dinner given to Prof. and Mrs. Herdman last week under the auspices of the Liverpool Biological Society. In responding to the toast proposed by Sir William M. Banks, Prof. Herdman was prevented from speaking on the principal object of the expedition, namely, his work on the pearl oyster, because the Government report had not been presented, but he gave an interesting account of other sections of his work and of visits to places of interest in and about Ceylon.

THe annual conversazione of the Society of Arts will be held on June 24 at the Royal Botanic Gardens, Regent's Park.

A MeEting of delegates representing a number of natural history and photographic societies was held at Croydon on Friday, May 9, Mr. W. W. Whitaker, F.R.S., being in the chair, to consider and set in motion a photographic survey of Surrey. It was resolved that a society be formed to be called "'The Photographic Survey of Surrey," and that its object be to preserve a record in permanent photographs of buildings of No. 1698 , VOL. 66] 